\title{
Microbiological and physicochemical evaluation of River Nile (Rosetta branch)
}

\author{
Amina E. Soliman ${ }^{1}$; Rashed A. Zaghloul²; Rasha M. El-Meihy²; Ehsan, A. Hanafy ${ }^{2}$; Hatem M. Ali ${ }^{1}$ \\ ${ }^{1}$ Water quality unit, Ministry of Water Resources and Irrigation, Egypt. \\ ${ }^{2}$ Agricultural Microbiology Department, Faculty of Agriculture, Benha University, Egypt. \\ Corresponding author: rashaelmehy@fagr.bu.edu.eg
}

\begin{abstract}
This study was carried out during period extended from January 2013 to December 2013 to evaluate the microbiological and physicochemical characteristics of Rosetta branch water, River Nile. The examination includes eight locations along Rosetta branch. Temperature values were ranged between 17.6 to $31.0^{\circ} \mathrm{C}$ while, $\mathrm{pH}$ values ranged between 7.16 to 7.98 during four seasons. Moreover, turbidity values were ranged between 1.90 to 33.7 NTU during all seasons. Regarding dissolved oxygen (DO) value, the lowest $(3.1 \mathrm{mg} / \mathrm{l})$ and the highest $(8.0$ $\mathrm{mg} / \mathrm{l})$ values were recorded during autumn and winter, respectively. Moreover, the highest (26.6 $\mathrm{mg} / \mathrm{l})$ and the lowest $(3.30 \mathrm{mg} / \mathrm{l})$ values of biological oxygen demand (BOD) were recorded during winter and autumn, respectively. Chemical oxygen demand (COD) values were ranged between 7.4 to $42.6 \mathrm{mg} / \mathrm{l}$ which recorded during winter season. Additionally, ammonia values were ranged between 0.22 to $7.70 \mathrm{mg} / \mathrm{l}$ during all four seasons. Nitrite values ranged between 0.002 to $0.071 \mathrm{mg} / \mathrm{l}$ during all four seasons. The lowest nitrate value $(0.10$ $\mathrm{mg} / \mathrm{l})$ and the highest value $(1.02 \mathrm{mg} / \mathrm{l})$ were recorded during summer and winter, respectively. Respecting the monthly changes in microbial counts of Rosetta branch, average log no. of total coliform was ranged between 1.84 to $6.88 \mathrm{CFU} / 100 \mathrm{ml}$, the highest log no. in most locations were recorded during July. While, average log no. of fecal coliform was ranged between 1.30 to $6.5 \mathrm{CFU} / 100 \mathrm{ml}$ during all months. Moreover, the highest counts of $\log$ no. was $(5.96 \mathrm{CFU} / 100 \mathrm{ml})$ and the lowest $\log$ no. was $(0.30 \mathrm{CFU} / 100 \mathrm{ml})$ of $E$. coli were recorded during August. Additionally, the highest log no. of fecal streptococci (4.85 CFU/100ml) was recorded during July.
\end{abstract}

Key words: Rosetta branch, microbiological, physicochemical, River Nile

\section{Introduction}

River Nile is the longest river in the world, located in the north-east of the continent of Africa, and stems specifically from Lake Victoria and ends in the Mediterranean Sea, a length of 6695 kilometers, and covers the Nile basin more than three million kilometers, it passes through 10 countries: the upstream States, Uganda, Ethiopia, Eritrea, Congo, Burundi, Tanzania, Rwanda, Kenya and the downstream states, Sudan and Egypt (Encyclopedia Britannica, 2017). The River Nile in Egypt splits into two branches, the first is Rosetta Branch located in Lower Egypt, the western limit of the Delta before the river pours into the Mediterranean Sea. Whereas, the second is the Damietta branch to the east (Salvini $\boldsymbol{e t}$ al., 2015). It also has four Rayahs (Canals) namely ElNassery, El-Behery, El-Menofy and El-Toufeky (Abdel-Aziz, 2005). Concerning the Rosetta branch, it is about $230 \mathrm{~km}$ in length with average width $180 \mathrm{~m}$ and average depth between 2-4 m. The Rosetta branch extends from Al-Qanatir Charity to the Mediterranean Sea at a length of $169 \mathrm{~km}$ and runs between five governorates (Giza, Menoufia, Gharbia, Beheira, Kafr El-Sheikh). There are five main drains along Rosetta branch with a quantity of 8.9 million $\mathrm{m}^{3} /$ day discharged from industrial, agricultural and waste water. These drains are Al-Rahawy, Sabal, ElTahreer, Zawiet El-Bahr and Tala (Ibrahim et al., 2017 a). Rosetta branch receives different types of pollution that affects and deteriorates its water quality through Al-Rahawy drain that receives all sewage of Giza Governorate in addition to agricultural and domestic wastes of Al-Rahway village and discharge these wastes $\left(400,000 \mathrm{~m}^{3} /\right.$ day $)$ directly without treatment into the branch (Tayel et a1., 2008). Moreover, Kafr El-Zayat industrial area, which include the industrial effluents from the factories of super phosphate and sulfur compounds, oil and soap industries and pesticides factories (Daboor, 2006). Additionally, several small agricultural drains that discharge their water into the branch in addition to sewage discharged from several cities and its neighboring villages that are distributed along the two banks of the Rosetta branch (El-Sayed, 2011). Nile River system receives a large quantity of industrial, agriculture and domestic wastewater. According to Rifaat and Mohamed (2004), Rosetta branch as part of this system, flows downstream Delta Barrage to the north-west about $225 \mathrm{~km}$ and ends with Idfina barrage which regulates the excess flow of the branch. It is considered the main source of fresh water for the western side of the Nile Delta. Idfina barrage regularly releases water to the Mediterranean Sea during winter closure period. Elewa et a1. (2009) concluded that Rosetta branch remains threatened by the increasing of human activities on the long term which affect the water quality characteristics. A1-Rahawy drain is the main source of pollution at the area of investigation due to the huge amount of domestic and agricultural wastes discharged into Rosetta branch. Water quality is a relative term that is defined as the characteristics of water that influence its suitability for a specific use through its physical, chemical, and biological nature. This nature could be altered through several contamination sources including: domestic, industrial, 
and agricultural wastes (FAO, 1997). The physiochemical parameters are considered as the most important principles in the identification of the nature, quality and type of the water (fresh, brackish or saline) for any aquatic ecosystem. These parameters included water temperature, $\mathrm{pH}$ value and transparency (turbidity) (Moustafa et a1., 2010) moreover, BOD (Abdo et a1., 2010) and COD (Garg et a1., 2010). Microbiological indicators for water pollution contains total coliforms, faecal coliforms, faecal streptococci and Escherichia coli (Ezzat et al., 2012). This study was carried out during period extended from January 2013 to December 2013 to evaluate the microbiological and physicochemical characteristics of Rosetta branch water, River Nile compared to Law No. 48. (1982).

\section{Materials and Methods}

\subsection{Locations of the study sites at Rosetta} branch, River Nile

The examination includes eight locations along Rosetta branch. The cods of sampling location with full of each site were described as follows in Table (1).

Table 1. Locations of the study sites at Rosetta branch, River Nile.

\begin{tabular}{c|c|l}
$\begin{array}{c}\text { Location } \\
\text { site }\end{array}$ & $\begin{array}{c}\text { Distance from Delta } \\
\text { Barrage }(\mathbf{K m})\end{array}$ & \multicolumn{1}{c}{ Description } \\
\hline N1 & 5.0 & Downstream Delta barrage-upstream El-Rahawy drain \\
N2 & 15.0 & Downstream El-Rahawy drain-upstream Sabal drain \\
N3 & 74.0 & Downstream Sabal drain-upstream El-Tahreer drain \\
N4 & 89.0 & Downstream El-Tahreer drain-upstream Zawiet El-Bahr drain \\
N5 & 103.0 & Downstream Zawiet El-Bahr drain-upstream Tala drain \\
N6 & 135.0 & Downstream Tala drain-downstream Abeg Village \\
N7 & 180.0 & Rosetta branch at Foua city \\
N8 & 203.0 & Rosetta branch upstream Idfina barrage \\
\hline
\end{tabular}

\subsection{Physicochemical examination}

Physicochemical analyses were performed according to the standard methods for examination of water and wastewater suggested by American Public Health Association (APHA, 2005). Temperature $\left({ }^{\circ} \mathrm{C}\right)$ was estimated using thermal thermometer. $\mathrm{PH}$ values were determined using portable $\mathrm{pH}$ meter with electrode (WTW Model pH 197). Turbidity values were determined using HACH-RATIO/XRturbidimeter gelex secondary turbidity standards (1800, 180, 18, 1.8 NTU). Dissolved oxygen (DO) was estimated using portable temperature/dissolved oxygen meter with oxygen and temperature probes (WTW Model Oxi 197) and expressed as mg/l at the same place and time of sampling. COD and BOD were measured gravimetrically determined according to Stirling (1985). Additionally, ammonia and nitrite and nitrate were determined according to Gloterman et al. (1978).

\subsection{Bacteriological analysis}

Total coliform count was determined using membrane filter technique according to standard method No.9222B (APHA, 2005) on M-Endo Agar LES medium (DIFCO, USA) and were recorded as CFU/100 ml. Fecal coliforms count were determined using membrane filter technique on M-FC agar medium (DIFCO, USA) according to standard method No. 9222D and No. 9230C (APHA, 2005). Whereas, E. coli detection was done according to the method described by Pettibone (1992) using multiple tube fermentation technique. Additionally, Fecal streptococci density was determined using membrane filter technique according to standard method No.9230 C (APHA, 2005) on M-Enterococcus agar medium (DIFCO, USA).

\section{Results and Discussion}

\subsection{Physiochemical characteristics of River Nile, Rosetta branch}

Physiochemical characteristics of Rosetta branch water were analyzed during the four seasons (Summer, Autumn, Winter and Spring) in 2013 at different sites.

\subsubsection{Temperature, $\mathrm{pH}$ values and turbidity of River Nile water, Rosetta branch}

Data in Table (2) showed the changes of temperature, $\mathrm{pH}$ and turbidity values in Nile's Rosetta branch water. Temperature values were ranged between $17.6-31.0^{\circ} \mathrm{C}$. The highest temperature $\left(31.0^{\circ} \mathrm{C}\right)$ was recorded during autumn in location No.8 (Rosetta branch upstream Idfina barrage) but the lowest value $\left(17.6^{\circ} \mathrm{C}\right)$ was recorded during winter in location No.1 (downstream Delta barrage upstream Al-Rahawy drain). Moreover, lower temperatures were recorded during winter followed by spring in all locations. Also, the lowest temperature during summer, autumn and spring were recorded in locations No. 1, 4 and 3, respectively. These results were in harmony with Ezzat et al. (2012) who reported that temperature changes ranged from $25.5^{\circ} \mathrm{C}$ to $27.7^{\circ} \mathrm{C}$ in drains outlets and between $25^{\circ} \mathrm{C}$ to $28.3^{\circ} \mathrm{C}$ along Rosetta branch sites during summer 2010 and winter 2011. Also, he said that temperature change depends mainly on the climatic conditions. In addition, El Gammal and El Shazely (2008) recorded that the temperature along Rosetta branch ranged from 20 to $30^{\circ} \mathrm{C}$ at various seasons. Similarly, results by Abdel-Satar et al. (2017) showed that temperature ranged between 17.8 to $18.9^{\circ} \mathrm{C}$ during winter and between 18.7 to $27.9{ }^{\circ} \mathrm{C}$ during spring. While, during summer and autumn the temperature 
ranged between 24.5 to $30.7^{\circ} \mathrm{C}$ and 20.5 to $26.8^{\circ} \mathrm{C}$, respectively.

Regarding the seasonally changes of $\mathrm{pH}$ at Nile's Rosetta branch, data presented in Table (2) indicated that $\mathrm{pH}$ values ranged between 7.16 to 7.98 . The highest value was recorded during winter in location No.1 (downstream Delta barrage-upstream AlRahawy drain) whereas, the lowest value was recorded during autumn in location No.7 (Rosetta branch at Foua city). Additionally, $\mathrm{pH}$ values were ranged between 7.86 to 7.42 during summer and between 7.16 to 7.94 during autumn. While, during summer and winter the $\mathrm{pH}$ values ranged between 7.68 to 7.98 and 7.35 to 7.92 , respectively. Also, data showed that the highest $\mathrm{pH}$ during summer and winter were recorded in location No.1 (downstream Delta barrage-upstream Al-Rahawy drain). While, the highest recorded $\mathrm{pH}$ during autumn and spring were in location No.8 (Rosetta branch upstream Idfina barrage) and No.5 (downstream Zawiet El-Bahr drainupstream Tala drain), respectively. Generally, the highest $\mathrm{pH}$ values in most under investigation sites were recorded during winter compared to other seasons. In this respect, El Gammal and El Shazely (2008) reported that $\mathrm{pH}$ values of 24 sites along the Nile from Aswan to Cairo ranged between 7.3 to 8.5 during winter and between 7.6 to 8.3 during spring. While, during summer and autumn $\mathrm{pH}$ values were ranged between 7.7 to 8.6 and 7.7 to 9.0 , respectively. Also, Ezzat et al. (2012) showed that $\mathrm{pH}$ values water samples collected from Rosetta branch in summer and winter seasons were ranged from 7.45 to 7.9. Moreover, Abdel-Satar et al. (2017) reported that $\mathrm{pH}$ in the Nile River was generally on the alkaline side.

Table 2. Seasonally changes in temperature, $\mathrm{pH}$ values and turbidity in various locations at Rosetta branch, River Nile

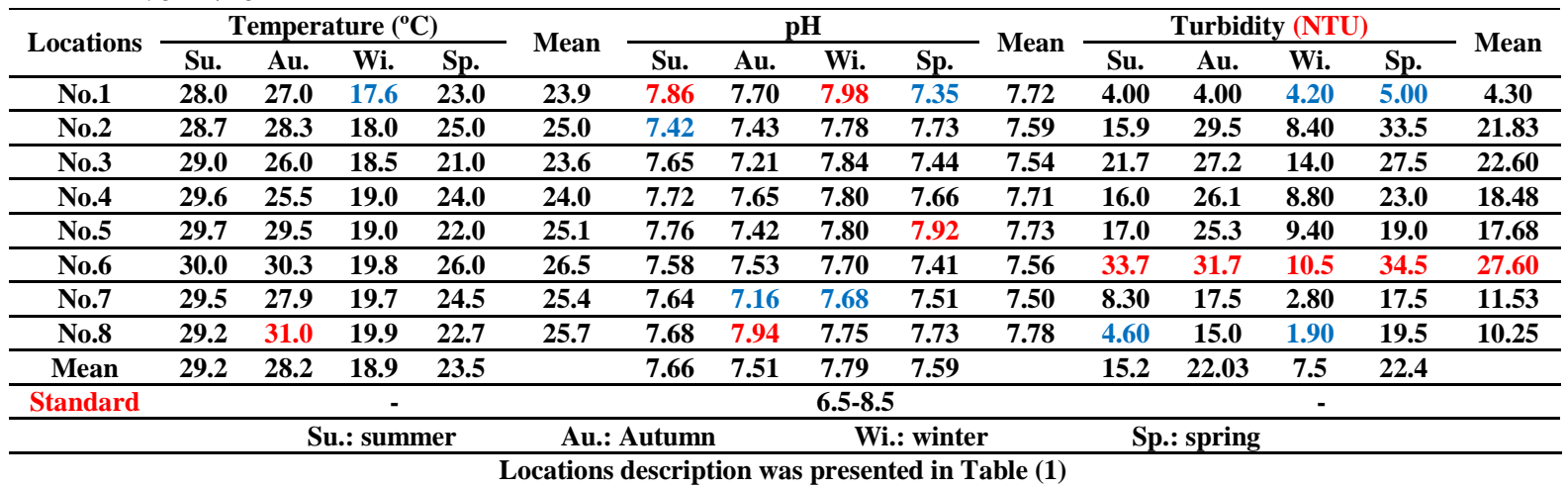

Turbidity is the measure of fine suspended matter in water, mostly caused by colloidal particles such as clay, silt, living and non-living organisms. In this respect, results in Table (2) clearly indicated that the highest value of turbidity was observed during spring in location No.6 (downstream Tala drain-downstream Abeg Village) at 34.5 NTU followed by the same location in summer at (33.7 NTU)). Whereas, the lowest value was in observed in winter in location No.8 (Rosetta branch upstream Idfina barrage) at 1.9 NTU. Moreover, site No (1) gave the lowest turbidity values during all seasons except during winter. Increasing values from up-stream to down-stream along the branch may be attributed to drains discharge (Abdel-Satar et al., 2017). Also, among of all water samples from different sites the detected values of turbidity were greater in site No.6 (downstream Tala drain-downstream Abeg Village) than other sites. This may be due to the sewage effluent. Also, obtained results showed that the turbidity values were ranged between 4.33 to $7,4.31$ to $7,1.9$ to 10.5 and 5 to 34.5 during summer, autumn, winter and spring, respectively. In additions lower values were observed during winter than other three seasons. This trend of results was true in most under study sites. These results were reversible to results by Abdel-Satar et al. (2017) who reported that transparency values were lower (turbidity was higher) during winter. Similar results were observed by Ezzat et al. (2012) who found that turbidity values ranged between 8-26.5 NTU in Rosetta branch during summer and winter seasons. They also reported that turbidity values were negatively correlated with $\mathrm{pH}$.

1.4.2. Dissolved oxygen (DO), chemical oxygen demand (COD) and biological oxygen demand (BOD5) values in Rosetta branch, River Nile water

DO is required for the metabolism of aerobic organisms and it influences organic decomposition. Is also often used as an indicator of water quality. Regarding DO concentration in understudying sites along Rosetta branch, data presented in Table (3) showed that the lowest and the highest DO values were recorded in site No.3 (downstream Sabal drainupstream El-Tahreer drain) during autumn at $3.1 \mathrm{mg} / \mathrm{l}$ and site No.1 (downstream Delta barrage-upstream Al-Rahawy drain) during winter at $8.0 \mathrm{mg} / \mathrm{l}$, respectively. During summer, DO values were higher than other three seasons in sites No.3,4,5,6 and 7. In addition, the highest DO values during summer was recorded in site No.7 (Rosetta branch at Foua city) whereas, the lowest values were recorded in site No.2 (downstream Al-Rahawy drain-upstream Sabal drain). The highest DO values during autumn, winter 
and spring were recorded in site No.1 (downstream Delta barrage-upstream El-Rahawy drain). While, the lowest DO values during autumn and spring were in site No.3 (downstream Sabal drain- upstream ElTahreer drain). Similar results were demonstrated by Abdel-Satar et al. (2017) who showed that DO values in all water samples from Rosetta branch were ranged between 4.1 to $13.2 \mathrm{mg} / \mathrm{l}, 5.4$ to $9.8 \mathrm{mg} / \mathrm{l}, 3.0$ to 9.8 $\mathrm{mg} / \mathrm{l}$ and 4.1 to $10.8 \mathrm{mg} / \mathrm{l}$ during winter, spring, summer and autumn, respectively. Also, El-Bouraie et al. (2011) indicated that DO values were ranged between 0.38 to $5.16 \mathrm{mg} / \mathrm{l}, 0.52$ to $5.12 \mathrm{mg} / \mathrm{l}, 0.50$ to $5.31 \mathrm{mg} / \mathrm{l}$ and 0.63 to $5.57 \mathrm{mg} / \mathrm{l}$ ) during winter, autumn, summer and spring, respectively. Moreover, Ezzat et al. (2012) stated that DO values in water samples collected from Rosetta branch were ranged from $1.7 \mathrm{mg} / \mathrm{l}$ to $6.8 \mathrm{mg} / \mathrm{l}$. They also found that the amount of DO depends highly on temperature that increase with decrease in temperature. And the depletion of DO could be anticipated to microbial decomposition of the excessive organic matter discharged directly from the drains.

Respecting the biological oxygen demand, BOD is a measure of the amount of dissolved oxygen removed from water by aerobic microorganisms for their metabolic requirements during the breakdown of organic matter. It also used to determine the level of organic pollution of water. Data presented in Table (3) showed that the lowest BOD values $(3.30 \mathrm{mg} / \mathrm{l})$ was recorded in site No.1 (downstream Delta barrageupstream Al-Rahawy drain) during autumn. While, the highest BOD value $(26.6 \mathrm{mg} / \mathrm{l})$ was recorded in site No.2 (downstream Al-Rahawy drain-upstream Sabal drain) during winter. Generally, the lowest BOD values were recorded in site No.1 (downstream Delta barrage-upstream Al-Rahawy drain) during all four seasons. On contrary, the highest BOD values during spring were recorded in site No.6 (downstream Tala drain-downstream Abeg Village) and during autumn and spring were recorded Generally, during autumn and spring the BOD values were higher than summer and winter in most sites. These results were in harmony with Ezzat et al. (2012) who reported that BOD in Rosetta branch were ranged from 5.5-52.0 $\mathrm{mg} / \mathrm{l}$. Also, Abdel-Satar et al. (2017) stated that BOD values were ranged between $(1.2-8.0 \mathrm{mg} / \mathrm{l}),(1.8-8.0$ $\mathrm{mg} / \mathrm{l}),(1.2-5.9 \mathrm{mg} / \mathrm{l})$ and $(1.8-6.5 \mathrm{mg} / \mathrm{l})$ during winter, spring, summer and autumn, respectively. Additionally, El-Bouraie $\boldsymbol{e t}$ al. (2011) indicated that BDO values were ranged between (1.0-130 mg/l), (2.0-110.0 mg/l), (1.0-80.0 mg/l) and (1.0-75.0 mg/l) during winter, autumn, summer and spring, respectively.

Table 3. Seasonally changes in dissolved oxygen, biological oxygen demand and chemical oxygen demand values in various locations at Rosetta branch, River Nile.

\begin{tabular}{|c|c|c|c|c|c|c|c|c|c|c|c|c|c|c|c|}
\hline \multirow[t]{2}{*}{ Locations } & \multicolumn{4}{|c|}{$\begin{array}{l}\text { Dissolved oxygen } \\
\text { DO (mg/l) }\end{array}$} & \multirow[t]{2}{*}{ Mean } & \multicolumn{4}{|c|}{$\begin{array}{c}\text { Biological oxygen demand } \\
\text { BOD }(\mathrm{mg} / \mathrm{l})\end{array}$} & \multirow[t]{2}{*}{ Mean } & \multicolumn{4}{|c|}{$\begin{array}{c}\text { Chemical oxygen demand } \\
\text { COD }(\mathrm{mg} / \mathrm{l})\end{array}$} & \multirow[t]{2}{*}{ Mean } \\
\hline & Su. & Au. & Wi. & Sp. & & Su. & Au. & Wi. & Sp. & & Su. & Au. & Wi. & Sp. & \\
\hline No.1 & 6.1 & 7.8 & 8.0 & 7.5 & 7.4 & 5.70 & 3.30 & 4.40 & 4.50 & 4.5 & 9.10 & 8.43 & 7.40 & 7.70 & 8.15 \\
\hline No.2 & 4.2 & 4.2 & 3.3 & 3.5 & 3.8 & 14.9 & 21.1 & 26.6 & 19.5 & 20.5 & 28.1 & 33.6 & 42.6 & 27.7 & 33.0 \\
\hline No.3 & 4.5 & 3.1 & 3.9 & 3.4 & 3.7 & 10.3 & 19.9 & 13.9 & 17.5 & 15.4 & 16.0 & 29.7 & 18.7 & 33.3 & 24.4 \\
\hline No.4 & 5.0 & 3.8 & 4.3 & 4.3 & 4.4 & 7.30 & 17.4 & 9.00 & 13.9 & 11.9 & 10.1 & 23.2 & 12.8 & 27.2 & 18.3 \\
\hline No.5 & 5.8 & 4.9 & 4.9 & 4.1 & 4.9 & 7.70 & 15.3 & 8.90 & 14.5 & 11.6 & 11.6 & 22.2 & 12.0 & 25.1 & 17.7 \\
\hline No.6 & 7.0 & 5.3 & 4.0 & 3.7 & 5.0 & 10.1 & 21.2 & 12.8 & 21.3 & 16.4 & 17.1 & 27.9 & 20.2 & 34.2 & 24.9 \\
\hline No.7 & 7.6 & 6.4 & 5.7 & 4.9 & 6.2 & 9.90 & 14.2 & 10.5 & 11.2 & 11.5 & 12.9 & 23.1 & 13.2 & 19.2 & 17.1 \\
\hline No.8 & 5.1 & 6.1 & 5.6 & 5.1 & 5.5 & 9.80 & 13.2 & 9.10 & 12.7 & 11.2 & 16.5 & 17.9 & 15.4 & 21.2 & 17.8 \\
\hline Mean & 5.7 & 5.2 & 4.9 & 4.6 & & 9.5 & 15.7 & 11.9 & 14.4 & & 15.2 & 23.3 & 17.8 & 24.5 & \\
\hline Standard & & & 6 & & & \multirow{2}{*}{\multicolumn{5}{|c|}{$\begin{array}{l}6 \\
\text { Wi: winter }\end{array}$}} & \multicolumn{5}{|c|}{10} \\
\hline \multicolumn{5}{|c|}{ Su: summer } & & & & & & & Sp: & ring & & & \\
\hline
\end{tabular}

Concerning the chemical oxygen demand (COD) values, data presented in Table (3) indicated that the lowest values were recorded in site No.1 (downstream Delta barrage-upstream Al-Rahawy drain) during all seasons. Whereas, the highest values were recorded in site No.2 (downstream Al-Rahawy drain-upstream Sabal drain) during all seasons except during spring. The highest COD during spring was in site No.6 (downstream Tala drain-downstream Abeg Village) with $34.21 \mathrm{mg} / \mathrm{l}$ followed by site No.3 (downstream Sabal drain- upstream El-Tahreer drain) with 33.34 $\mathrm{mg} / \mathrm{l}$. Generally, higher COD values where recorded in sites No.3,4,5,7 and 8 during spring than other seasons. Moreover, COD values recorded during autumn and springs were higher than winter and summer. This trend of result was true in most sites. COD values were ranged between (2.9-111.0 mg/l),
(3.7-65.4 mg/l), (3.4-78.5 mg/l) and (3.6-81.3 mg/l) during winter, spring, summer and autumn, respectively (Abdel-Satar et al., 2017). Also, ElBouraie et al. (2011) indicated that CDO values were ranged between (16.0-198.0 mg/l), (4.0-179.0 mg/l), $(5.0-189.0 \mathrm{mg} / \mathrm{l})$ and $(4.0-141.0 \mathrm{mg} / \mathrm{l})$ during winter, autumn, summer and spring, respectively.

\subsubsection{Ammonia, nitrite and nitrate values in River Nile, Rosetta branch water}

Ammonia is a form of the nitrogenous compounds present in nature and is essential for the growth and reproduction of living organisms. The ammonia ion is either released from proteinaceous organic matter and urea or is synthesized by industrial processes. In this respect, data presented in Table (4) showed the comparison between the results of Ammonia, Nitrite and Nitrate in River Nile-Rosetta branch during 2013. 
Ammonia values ranged from 0.22 to $7.70 \mathrm{mg} / \mathrm{l}$ during winter in all sites. Additionally, Ammonia concentration in site No.1 (downstream Delta barrageupstream Al-Rahawy drain) was lower than other sites. While, the highest values of ammonia were recorded in site No.2 (downstream Al-Rahawy drainupstream Sabal drain) than other sites. This trend of results was observed during all four seasons. Also, data indicated that the ammonia concentration was lower in summer than other seasons. Similar trend of results was observed by Ezzat et al. (2012) who reported that $\mathrm{NH}_{3}$ concentrations ranged from 1.25$8.35 \mathrm{mg} / \mathrm{l}$ in Rosetta branch. Additionally, AbdelSatar et al. (2017) reported that $\mathrm{NH}_{3}$ values were ranged between (21-3403 $\mu \mathrm{g} / \mathrm{l}),(33-17928 \mu \mathrm{g} / \mathrm{l})$, (29$2237 \mu \mathrm{g} / \mathrm{l})$ and (33-11409 $\mu \mathrm{g} / \mathrm{l})$ during winter, spring, summer and autumn, respectively.

Regarding the nitrite $\left(\mathrm{NO}_{2}\right)$ concentration in Rosetta branch, data in Table (4) showed that $\mathrm{NO}_{2}$ values ranged between $(0.004-0.035 \mathrm{mg} / \mathrm{l}),(0.002$ -
$0.045 \mathrm{mg} / \mathrm{l}),(0.010-0.050 \mathrm{mg} / \mathrm{l})$ and (0.010-0.071 $\mathrm{mg} / \mathrm{l})$ during summer, autumn, winter and spring, respectively. The highest $\mathrm{NO}_{2}$ values in different seasons were recorded in site No.8 (Rosetta branch upstream Idfina barrage) during summer, in site No.5 downstream Zawiet El-Bahr drain-upstream Tala drain) during autumn and winter. Whereas, the highest $\mathrm{NO}_{2}$ value during winter was recorded in site No.7 (Rosetta branch at Foua city). Generally, the lowest $\mathrm{NO}_{2}$ values during all seasons were recorded in site No.1 (downstream Delta barrage-upstream AlRahawy drain). These results were in harmony with those obtained by Abdel-Satar et al. (2017) who reported that $\mathrm{NO}_{2}$ values were ranged between (4.4$86.4 \mu \mathrm{g} / \mathrm{l}),(0.5-167.3 \mu \mathrm{g} / \mathrm{l}),(4.6-694.3 \mu \mathrm{g} / \mathrm{l})$ and $(5.0-$ $1282 \mu \mathrm{g} / \mathrm{l})$ during winter, spring, summer and autumn, respectively. On contrast, Ezzat et al. (2012) showed that the $\mathrm{NO}_{2}$ values in all water samples from Rosetta branch during summer and winter were constant and no changes were observed.

\begin{tabular}{|c|c|c|c|c|c|c|c|c|c|c|c|c|c|c|c|}
\hline \multirow[t]{2}{*}{ Locations } & \multicolumn{4}{|c|}{$\begin{array}{c}\text { Ammonia }\left(\mathrm{NH}_{4}{ }^{+}\right) \\
(\mathrm{mg} / \mathrm{l})\end{array}$} & \multirow[t]{2}{*}{ Mean } & \multicolumn{4}{|c|}{$\begin{array}{c}\text { Nitrite }\left(\mathrm{NO}^{-2}\right) \\
(\mathrm{mg} / \mathrm{l})\end{array}$} & \multicolumn{5}{|c|}{$\begin{array}{l}\text { Nitrate }\left(\mathrm{NO}^{+3}\right) \\
(\mathrm{mg} / \mathrm{l})\end{array}$} & \multirow{2}{*}{ Mean } \\
\hline & Su. & Au. & Wi. & Sp. & & Su. & Au. & Wi. & Sp. & & Su. & Au. & Wi. & Sp. & \\
\hline No.1 & 0.48 & 0.31 & 0.22 & 0.33 & 0.34 & 0.004 & 0.002 & 0.010 & 0.010 & 0.007 & 0.10 & 0.11 & 0.16 & 0.03 & 0.10 \\
\hline No.2 & 3.00 & 5.52 & 7.70 & 6.72 & 5.74 & 0.030 & 0.017 & 0.040 & 0.041 & 0.032 & 0.65 & 0.77 & 1.02 & 0.92 & 0.84 \\
\hline No.3 & 2.10 & 4.31 & 6.30 & 5.35 & 4.52 & 0.026 & 0.031 & 0.032 & 0.023 & 0.028 & 0.35 & 0.62 & 0.75 & 0.71 & 0.61 \\
\hline No.4 & 0.80 & 3.21 & 3.20 & 5.13 & 3.09 & 0.018 & 0.007 & 0.020 & 0.017 & 0.016 & 0.50 & 0.61 & 0.78 & 0.42 & 0.58 \\
\hline No.5 & 1.80 & 3.44 & 4.00 & 4.31 & 3.39 & 0.020 & 0.045 & 0.030 & 0.071 & 0.042 & 0.40 & 0.51 & 0.62 & 0.55 & 0.52 \\
\hline No.6 & 1.50 & 3.56 & 6.90 & 4.71 & 4.17 & 0.025 & 0.034 & 0.035 & 0.013 & 0.027 & 0.56 & 0.43 & 0.50 & 0.56 & 0.51 \\
\hline No.7 & 0.80 & 2.71 & 5.80 & 2.11 & 2.86 & 0.030 & 0.024 & 0.050 & 0.011 & 0.029 & 0.48 & 0.44 & 0.39 & 0.41 & 0.43 \\
\hline No.8 & 0.90 & 0.93 & 5.40 & 1.95 & 2.30 & 0.035 & 0.032 & 0.025 & 0.021 & 0.28 & 0.40 & 0.31 & 0.32 & 0.34 & 0.34 \\
\hline Mean & 1.42 & 3.00 & 4.94 & 3.83 & & 0.024 & 0.024 & 0.030 & 0.026 & & 0.43 & 0.48 & 0.57 & 0.49 & \\
\hline $\begin{array}{l}\text { Standard } \\
\text { law48/1982 }\end{array}$ & \multicolumn{5}{|c|}{0.5} & \multicolumn{4}{|c|}{-} & & \multirow{2}{*}{\multicolumn{4}{|c|}{2}} & \\
\hline & & & Su: & nmer & & utumn & & Wi: wi & & & & & & & \\
\hline
\end{tabular}

Respecting the nitrate concentration in under investigation sites along Rosetta branch, data in Table (4) showed that the lowest and the highest values were recorded in site No.1 (downstream Delta barrageupstream Al-Rahawy drain) during summer and in site No.2 (downstream Al-Rahawy drain-upstream Sabal drain) during winter, respectively. This trend of results was true during all four seasons. Nitrate concentration recorded in sites No.6 (downstream Tala draindownstream Abeg Village), No.7 (Rosetta branch at Foua city) and No.8 (Rosetta branch upstream Idfina barrage) were higher during summer than other seasons. While, in sites No.3 (downstream Sabal drain-upstream El-Tahreer drain), No.4 (downstream El-Tahreer drain-upstream Zawiet El-Bahr drain) and No.5 (downstream Zawiet El-Bahr drain-upstream Tala drain) were higher during winter than other seasons. Generally, the highest concentrations of all determined compounds were recorded in winter. These results were in agreement with Ezzat et al. (2012) who showed that high positive correlations between ammonia and nitrate concentration in all water samples collected from Rosetta branch. This was attributed to the oxidation of ammonia to nitrate by aerobic bacteria. also, they reported that normal
$\mathrm{NO}_{3}$ values were recorded in all sites along Rosetta branch. Moreover, Abdel-Satar et al. (2017) recorded the nitrate concentration in River Nile during all four seasons. They found that $\mathrm{NO}_{3}$ values were ranged between $(8-550 \mu \mathrm{g} / \mathrm{l}),(19-1878 \mu \mathrm{g} / \mathrm{l}),(3-1864 \mu \mathrm{g} / \mathrm{l})$ and (10-1087 $\mu \mathrm{g} / \mathrm{l})$ during winter, spring, summer and autumn, respectively.

\subsection{Bacteriological examination of Rosetta branch, River Nile water}

\subsubsection{Total coliform counts (TC)}

Data presented in Table (5) clearly indicated that higher T.C during all months were recorded in site No.2 (downstream Al-Rahawy drain-upstream Sabal drain) and the highest T.C was recorded during August (6.88. CFU/ml). In addition, the highest coliform counts in all locations except No.2 and No.8 were recorded during July and the highest counts in location No.8 was observed during June. Whereas, the lowest log. were observed in site No.8 (Rosetta branch upstream Idfina barrage). In general, location No.2 (downstream El-Rahawy drain-upstream Sabal drain) was more polluted than other locations, while, site No.8 (Rosetta branch upstream Idfina barrage) was the lower polluted site. 
Table 5. Monthly changes in average log no. of total coliform in various locations at Rosetta branch, River Nile.

\begin{tabular}{|c|c|c|c|c|c|c|c|c|c|}
\hline \multirow{2}{*}{ Months } & \multicolumn{9}{|c|}{ Locations } \\
\hline & No.1 & No. 2 & No.3 & No.4 & No.5 & No.6 & No.7 & No.8 & Mean \\
\hline January & 3.69 & 6.44 & 4.34 & 3.23 & 3.27 & 3.11 & 2.84 & 1.84 & 3.59 \\
\hline February & 3.77 & 6.53 & 4.41 & 3.36 & 3.32 & 3.14 & 2.77 & 1.95 & 3.65 \\
\hline March & 3.84 & 6.60 & 4.47 & 3.38 & 3.44 & 3.23 & 3.00 & 2.00 & 3.74 \\
\hline April & 3.90 & 6.67 & 4.53 & 3.50 & 3.46 & 3.27 & 3.07 & 2.00 & 3.8 \\
\hline May & 4.00 & 6.79 & 4.68 & 3.57 & 3.63 & 3.41 & 3.17 & 2.20 & 3.93 \\
\hline June & 4.11 & 6.83 & 4.77 & 3.72 & 3.69 & 3.49 & 3.32 & 2.27 & 4.03 \\
\hline July & 4.14 & 6.87 & 4.86 & 3.90 & 3.71 & 3.62 & 3.34 & 2.23 & 4.08 \\
\hline August & 4.11 & 6.88 & 4.83 & 3.88 & 3.68 & 3.49 & 3.27 & 2.25 & 4.05 \\
\hline September & 3.95 & 6.76 & 4.65 & 3.59 & 3.61 & 3.38 & 3.17 & 2.17 & 3.91 \\
\hline October & 3.95 & 6.69 & 4.57 & 3.54 & 3.49 & 3.32 & 3.14 & 2.11 & 3.85 \\
\hline November & 3.95 & 6.71 & 4.60 & 3.54 & 3.47 & 3.34 & 3.17 & 2.14 & 3.87 \\
\hline December & 3.84 & 6.60 & 4.46 & 3.44 & 3.44 & 3.23 & 3.04 & 1.95 & 3.75 \\
\hline Mean & 3.94 & 6.69 & 4.59 & 3.55 & 3.51 & 3.33 & 3.10 & 2.09 & \\
\hline
\end{tabular}

Locations description was presented in Table (1)

Abo-State et al. (2014) reported that the microbial water quality along the River Nile varies with location and depends on flow rate, water use, population density, sanitation systems, domestic and industrial discharges. Also, Rosetta branch is polluted at the discharge of Al-Rahway drain, where most probable number of TC reach $90 \times 10^{6} \mathrm{CFU} / 100 \mathrm{ml}$.This drain discharges $28 \times 10^{4} \mathrm{~m}^{3} /$ day, of which $193 \times 10^{2} \mathrm{~m}^{3}$ to Rosetta Nile. At Cairo $120 \mathrm{~km}$ downstream from the Delta barrage the Rosetta branch receives polluted in flows from three drains (Al-Rahawy, Sabal and Tala) and from industry at Kafr El-Zayat (Rabeh, 2009). Also, Ezzat et al., (2012) reported that the mean values of TBC were ranged between $\left(1.8 \times 10^{2-} 87 \mathrm{x}\right.$ $\left.10^{4} \mathrm{CFU} / 100 \mathrm{ml}\right)$ and $\left(1.3 \times 10^{2}-71 \times 10^{4}\right.$ $\mathrm{CFU} / 100 \mathrm{ml})$ in water samples collected from Rosetta branch during winter and summer, respectively. While, the mean counts. of total coliform (TC) were ranged between $\left(51 \times 10^{2}-27 \times 10^{4} \mathrm{CFU} / 100 \mathrm{ml}\right)$ in water samples collected from Rosetta branch during winter and summer. Additionally, Ali et al. (2011) reported that populations of total coliforms, faecal coliforms and faecal streptococci ranged from 25 to 1800, 9 to 1800 and 8 to $1800 \mathrm{MPN} / 100 \mathrm{ml}$, respectively in upstream and middle stream collected water samples on River Nile.

1.5.2. Fecal coliform counts in various locations at Rosetta branch, River Nile

The monthly changes in fecal coliform log. $(\mathrm{CFU} / \mathrm{ml})$ in various locations along Rosetta branch, River Nile water were showed in Table (6). The highest log. no of fecal coliform $(6.51 \mathrm{CFU} / 100 \mathrm{ml})$ was recorded in site No.2 (downstream Al-Rahawy drain-upstream Sabal drain) during July and August. Whereas, the lowest log. (1.30 CFU/100 ml) was recorded in site No.8 (Rosetta branch upstream Idfina barrage) during February. Moreover, this was the only location complying with the international standard limits of Ibrahim et al. (2017 b), in which FC count didn't exceed 2 CFU/100 $\mathrm{ml}$ in drinking water. Meanwhile, about $87.5 \%$ of the under-investigation sites along Rosetta branch don't achieve these international standards. Generally, data indicated that the site No.2 was the highest polluted site, while, site No.8 was the lowest polluted one. This trend was true during all months. Also, data showed that the summer months (June, July and August) were polluted more than other year months. This trend was true in all under study sites. Moreover, the lowest fecal coliforms were counted during February in all sites. The use of indicator bacteria such as faecal coliforms (FC) for assessment of faecal pollution and possible water quality deterioration in fresh water sources is widely used (Sabae and Rabeh, 2007). Also, Ezzat et al. (2014) reported that fecal coliforms count in Rosetta branch ranged between 650 and $14 \times 10^{5}$ CFU/100 ml. Abo-State et al. (2014) showed that the most probable number of faecal coliforms (FC) reach $25 \times 10^{5}$ CFU/100ml.During February 2001 "winter season" Faecal coliform ranged from $1.7 \times 10^{2}$ $\mathrm{CFU} / 100 \mathrm{ml}$ to $1.3 \times 10^{3} \mathrm{CFU} / 100 \mathrm{ml}$ at Kafr El-Zayat after factories. FC was $11-3.3 \times 10^{3} \mathrm{MPN} 100 / \mathrm{ml} /$, with annual average $7.6 \times 10^{2} \mathrm{MPN} / 100 \mathrm{ml}$ during the period from summer 1994 to spring 1996 (Rabeh, 2009). Also, Ezzat et al. (2002) indicated that during February 2001, FC ranged from $1.7 \times 10^{2} 100 / \mathrm{ml}$ (upstream of Edfina Barrage) to $1.3 \times 10^{3} 100 / \mathrm{ml}$ at Kafr El-Zayat. The highest counts were at Kafr ElZayat, after which the water complied with WHO Guidelines for irrigation.

Table 6. Monthly changes in average log no. of fecal coliform in various locations at Rosetta branch, River Nile. 


\begin{tabular}{|c|c|c|c|c|c|c|c|c|c|}
\hline \multirow{2}{*}{ Months } & \multicolumn{9}{|c|}{ Locations } \\
\hline & No.1 & No.2 & No.3 & No.4 & No.5 & No.6 & No.7 & No.8 & Mean \\
\hline January & 3.30 & 6.14 & 3.90 & 2.77 & 2.69 & 2.60 & 2.36 & 1.49 & 3.15 \\
\hline February & 3.07 & 5.95 & 3.60 & 2.60 & 2.60 & 2.47 & 2.25 & 1.30 & 2.98 \\
\hline March & 3.44 & 6.23 & 3.95 & 2.95 & 2.95 & 2.69 & 2.51 & 1.69 & 3.30 \\
\hline April & 3.46 & 6.39 & 4.11 & 3.0 & 3.07 & 2.95 & 2.59 & 1.76 & 3.41 \\
\hline May & 3.57 & 6.39 & 4.20 & 3.07 & 3.07 & 3.0 & 2.69 & 1.82 & 3.47 \\
\hline June & 3.64 & 6.47 & 4.27 & 3.14 & 3.17 & 3.07 & 2.70 & 1.91 & 3.54 \\
\hline July & 3.81 & 6.51 & 4.39 & 3.30 & 3.11 & 3.0 & 2.90 & 1.90 & 3.16 \\
\hline August & 3.69 & 6.51 & 4.27 & 3.14 & 3.17 & 3.07 & 2.74 & 1.89 & 3.56 \\
\hline September & 3.54 & 6.41 & 4.14 & 3.0 & 3.07 & 2.95 & 2.64 & 1.79 & 3.44 \\
\hline October & 3.47 & 6.34 & 4.11 & 2.95 & 2.95 & 2.90 & 2.56 & 1.73 & 3.37 \\
\hline November & 3.30 & 6.17 & 3.95 & 2.90 & 2.84 & 2.69 & 2.32 & 1.60 & 3.22 \\
\hline December & 3.23 & 6.07 & 3.69 & 2.69 & 2.77 & 2.60 & 2.34 & 1.39 & 3.09 \\
\hline Mean & 3.46 & 6.29 & 4.05 & 2.95 & 2.95 & 2.83 & 2.55 & 1.68 & \\
\hline
\end{tabular}

Locations description was presented in Table (1)

1.5.3. Fecal streptococci counts in various locations at Rosetta branch, River Nile water.

Data presented in Table (7) indicated the monthly changes in average log no. of fecal streptococci $(\mathrm{CFU} / \mathrm{ml})$ in various locations along Rosetta branch, River Nile. The highest fecal streptococci log. (4.85 CFU/100ml) was recorded in site No.2 (downstream Al-Rahawy drain-upstream Sabal drain) during July. Whereas, the lowest count $(0.77 \mathrm{CFU} / 100 \mathrm{ml})$ was recorded in site No.8 (Rosetta branch upstream Idfina barrage) during Winter (January and February). Also, data showed that the lowest log no. in all sites were observed during February. Generally, sites in Rosetta branch exceeding $1000 \mathrm{CFU} / 100 \mathrm{ml}$ were reported out of international standard limits by Ibrahim et al. (2017 b). Moreover, fecal streptococci log. were lower in site No.8 than other sites. This was true during all months. While, the log. was higher in site No.2 than other sites during all months of year. In addition, Fecal streptococci log. were lower and higher during February and July, respectively. This trend was true in most sites.

Table 7. Monthly changes in average log no. of fecal streptococci in various locations at Rosetta branch, River Nile.

\begin{tabular}{|c|c|c|c|c|c|c|c|c|c|}
\hline \multirow{2}{*}{ Months } & \multicolumn{9}{|c|}{ Locations } \\
\hline & No.1 & No.2 & No.3 & No.4 & No.5 & No.6 & No.7 & No.8 & Mean \\
\hline January & 1.23 & 3.99 & 2.44 & 1.57 & 1.46 & 1.36 & 1.0 & 0.77 & 1.73 \\
\hline February & 1.04 & 3.82 & 2.25 & 1.32 & 1.23 & 1.20 & 0.90 & 0.77 & 1.57 \\
\hline March & 1.47 & 4.23 & 2.70 & 2.77 & 1.69 & 1.55 & 1.38 & 1.14 & 2.11 \\
\hline April & 1.62 & 4.49 & 2.84 & 1.91 & 1.80 & 1.83 & 1.51 & 1.38 & 2.17 \\
\hline May & 1.75 & 4.55 & 2.94 & 2.0 & 1.92 & 1.88 & 1.62 & 1.47 & 2.27 \\
\hline June & 1.83 & 4.63 & 2.98 & 2.04 & 1.96 & 1.93 & 1.65 & 1.41 & 2.30 \\
\hline July & 1.04 & 4.85 & 3.07 & 2.20 & 2.25 & 2.07 & 1.95 & 1.59 & 2.38 \\
\hline August & 1.90 & 4.72 & 3.0 & 2.11 & 2.04 & 2.0 & 1.72 & 1.47 & 2.37 \\
\hline September & 1.72 & 4.53 & 2.91 & 1.97 & 1.90 & 1.87 & 1.62 & 1.39 & 2.24 \\
\hline October & 1.65 & 4.46 & 2.88 & 1.98 & 1.91 & 1.84 & 1.54 & 1.38 & 2.21 \\
\hline November & 1.53 & 4.32 & 2.75 & 1.84 & 1.74 & 1.72 & 1.39 & 1.14 & 2.05 \\
\hline December & 1.30 & 4.17 & 2.62 & 1.69 & 1.61 & 1.57 & 1.30 & 1.0 & 1.91 \\
\hline Mean & 1.51 & 4.39 & 2.78 & 1.95 & 1.79 & 1.74 & 1.46 & 1.24 & \\
\hline
\end{tabular}

It is noticeable that a gradual increase in bacterial indicators counts (TC, FC\& FS) from upstream to downstream, which might be attributed to the drains discharge into the branch, this agrees with the results of Abdo (2002) and Ezzat (2008). This finding agrees with Ezzat et al. (2014) who found that fecal streptococci counts in Rosetta branch ranged between (8-11) $10^{4} \mathrm{CFU} / 100 \mathrm{ml}$.

Also, Abo-State et al. (2014) revealed that $99 \%$ of 116 fecal streptococci samples collected from 11 locations at Rosetta branch ranged between $\left(1.0 \times 10^{1}\right.$ $7.0 \times 10^{4} \mathrm{CFU} / \mathrm{ml}$ ) during the year seasons. Generally, sites in Rosetta branch exceeding 1000 CFU/100 ml 
were reported out of international standard limits (Abdo, 2013). The data revealed that there is a gradual increase in bacterial indicators counts from upstream to downstream, which might be attributed to the drains discharge into the branch, this agrees with the results of Ezzat (2008). The use of indicator bacteria such as faecal streptococci (FS) for assessment of faecal pollution and possible water quality deterioration in fresh water sources is widely used (Sabae and Rabeh, 2007).

Fecal streptococci also belong to the traditional indicators of fecal pollution. Fecal streptococci are Gram-positive, catalase-negative, non-spore forming cocci that grow at $35^{\circ} \mathrm{C}$ (George et al., 2004). Ali et al. (2015) reported that microbiological analysis of the water samples collected from two sites in River Nile; after and before El-Sail drain showed an increase in total bacterial counts in site II than Site I, while there was no difference between the two sites in the sporeforming bacterial count. Coliform bacteria were detected in the two sites with four-fold increases in site II than site I, similarly the fecal coliform increased to about five folds in site II than site I. On the other hand, there was no significant difference in fecal
Streptococcus count in both sites. The FC: FS ratio was 0.5 in site I and 2.5 for site II.

\subsubsection{Escherichia coli counts in various locations at Rosetta branch, River Nile}

The monthly changes in coli counts $(\mathrm{CFU} / \mathrm{ml})$ in various locations at Rosetta branch, River Nile water were presented in Table (8). The highest (5.96 $\mathrm{CFU} / 100 \mathrm{ml})$ and the lowest $(0.30 \mathrm{CFU} / 100 \mathrm{ml})$ E. coli log. were recorded in sites No.2 (downstream ElRahawy drain-upstream Sabal drain) and No.8 (Rosetta branch up stream Idfina barrage) during August, respectively. Concerning the microbiological studies conducted earlier have reported high coli with the range between $1.0 \times 10^{1}$ and $1.3 \times 10^{5} \mathrm{CFU} / \mathrm{ml}$ during spring, summer, autumn and winter (AboState et al., 2014). They recorded maximum count during summer and autumn. This study was incomplete accordance with that observed by Sabae et al. (2006) the seasonal runoff was the main cause affecting the coliform level within Rosetta water system especially in summer and autumn, while domestic discharges and agricultural wastes were the main cause of microbiological water quality deterioration Rosetta water.

Table 8. Monthly changes in average log no. of Escherichia coli in various locations at Rosetta branch, River Nile.

\begin{tabular}{|c|c|c|c|c|c|c|c|c|c|}
\hline \multirow{2}{*}{ Months } & \multicolumn{9}{|c|}{ Locations } \\
\hline & No.1 & No.2 & No.3 & No.4 & No.5 & No.6 & No.7 & No.8 & Mean \\
\hline January & 2.84 & 5.54 & 3.32 & 2.32 & 2.11 & 2.14 & 2.0 & 0.90 & 2.65 \\
\hline February & 2.69 & 5.41 & 3.20 & 2.17 & 1.96 & 1.95 & 1.84 & 0.84 & 2.51 \\
\hline March & 2.95 & 5.59 & 3.38 & 2.38 & 2.17 & 2.20 & 2.11 & 1.07 & 2.73 \\
\hline April & 2.90 & 5.69 & 3.44 & 2.43 & 2.25 & 2.20 & 2.11 & 1.11 & 2.77 \\
\hline May & 3.07 & 5.83 & 3.61 & 2.60 & 2.38 & 2.39 & 2.30 & 1.27 & 2.93 \\
\hline June & 3.17 & 5.25 & 3.75 & 2.67 & 2.46 & 2.46 & 2.36 & 1.30 & 2.93 \\
\hline July & 3.30 & 5.94 & 3.89 & 2.86 & 2.59 & 2.59 & 2.46 & 1.44 & 3.13 \\
\hline August & 3.23 & 5.96 & 3.68 & 2.74 & 2.54 & 2.54 & 2.38 & 0.30 & 2.92 \\
\hline September & 3.14 & 5.85 & 3.61 & 2.60 & 2.38 & 2.36 & 2.30 & 1.07 & 2.91 \\
\hline October & 3.04 & 5.77 & 3.53 & 2.53 & 2.30 & 2.25 & 2.20 & 1.0 & 2.83 \\
\hline November & 3.07 & 5.79 & 3.56 & 2.50 & 2.38 & 2.36 & 2.20 & 1.0 & 2.86 \\
\hline December & 2.95 & 5.62 & 3.36 & 2.38 & 2.11 & 2.14 & 2.04 & 1.07 & 2.71 \\
\hline Mean & 3.03 & 5.69 & 3.53 & 2.52 & 2.30 & 2.29 & 2.19 & 1.03 & \\
\hline
\end{tabular}

Locations description was presented in Table (1)

Also, data clearly indicated that the lowest $E$. coli log. were observed in February. This was true in all under studying sites. Whereas, the highest log. were recorded during July in all sites except site No.2. Moreover, the site No. 2 was polluted more than other sites during all months. While, the site No (8) was less polluted than other sites. Generally, summer months showed higher log. than winter months. Also, sites No.1, 2, 3 and 4 were more polluted than the others. This trend was during all months. Currently, coliforms and $E$. coli are a great importance among bacterial indicators used in water quality definition and health risk (Giannoulis et al., 2005). E. coli strains are a natural and essential part of the bacterial flora in the gut of humans and animals. Most E. coli strains are non-pathogenic and reside harmlessly in the colon. However, certain serotypes play a role in intestinal and extra-intestinal diseases such as urinary tract infections (Gordon and Fitzgibbon, 1999).

\section{Conclusion}

The water quality along the studied locations in Rosetta branch is remarkably influenced by wastewater discharge from drains located on its sides regarding physicochemical and bacteriological characteristics. The study reflects strong evidence for bacterial contamination in Rosetta branch resulting from the impact of drains which was remarkable from Al-Rahawy drain. In addition to the untreated domestic wastes from villages distributed along the drain discharging directly their wastes, Al-Rahawy 
drain collects significant domestic wastes and sewage from greater Cairo represented by Zenain and Abu Rawash sewage treatment stations. In Rosetta branch, the bacterial contamination was maximum directly downstream the drains and decrease gradually far downstream. The self-purification and dilution effect could interpret the decreased gradual improvement recognized at the end of the Rosetta branch.

\section{References}

Abdel-Aziz, G.S. 2005. Study on the water quality of the Nile River with relation to environmental condition at El-Kanater El-Khyria region. M.Sc. In Microbiology, Fac. of Sci., Al-Azhar Univ., Cairo, Egypt.

Abdel-Satar, A.M., Ali, M.H., Goher, M.E. 2017. Indices of water quality and metal pollution of Nile River, Egypt. Egypt. J. Aqua. Res., 43:21-29.

Abdo, M.H. 2002. Environmental studies on the Rosetta branch and some chemical applications on the area extend from ElKanater El-Khyria to KafrEl-Zyat City. Ph.D., Fac. Sci., Ain Shams Univ., Cairo, Egypt.

Abdo, M.H. 2013. Physicochemical studies on the pollutants effect in the aquatic environment of Rosetta branch River Nile, Egypt. Life Sci. J., 10:493-501.

Abdo, M.H.; Sabae, S.Z.; Haroon, B.M.; Refaat, B.M. and Mohammad, A.S. 2010. Physicochemical characteristics, microbiological assessment and antibiotic susceptibility of pathogenic bacteria of Ismailia Canal water, River Nile, Egypt. J. Am. Sci., 6:234-250.

Abo-State, M.A.; El-Gamal, M.S.; El-Danasory, A. and Mabrouk, M.A. 2014). Prevalence of Enterobacteriaceae and Streptococcus faecalis in surface water of Rosetta branch and its drains of River Nile, Egypt. World Appl. Sci. J., 31(11):1873-1880.

Ali, S.M.; Sabae, S.Z.; Fayez, M.; Monib, M. and Hegazi, N.A. 2011. The influence of agroindustrial effluents on River Nile pollution. J. Adv. Res., 2:85-95.

Ali, S.M.; Yones, E.M.; Kenawy, A.M.; Ibrahim, T.B. and Abbas, W.T. 2015. Effect of El-Sail Drain Wastewater on Nile Tilapia (Oreochromis niloticus) from River Nile at Aswan, Egypt. J. Aqua. Res. Develop., 6(1):1-7.

American Public Health Association "APHA" (2005). Standard methods for the examination of water and wastewater ( $21^{\text {st }}$ ed.), Washington, D.C.

Daboor, S.M. 2006. Studied on bacterial flora and its role in the cleanup of hazardous pollutants in the River Nile, Ph.D., Fac. Sci. Zagazig Univ., Egypt.

Egyptian Wakayeh, 2013. Law $48 / 1982$ for the protection of the River Nile and its waterways from pollution. Decree of 2013, Official Journal , Issue no.22.

EI Bouraie, M.; Yehia, M.M.; Motawea, Eman, A. and Mohamed, Gehad, G. 2011. Water quality of
Rosetta branch in Nile delta, Egypt. J. SUO-Mires and Peat., 62(1):31-37.

Elewa, A.A.; Shehata, M.B.; Mohamed, L.F.; Badr, M.H. and Abdel-Aziz, G.S. 2009. Water quality characteristics of the River Nile at delta barrage with special reference to Rosetta branch. Global J. Environ. Res.,3:1-6.

El-Gammal, H.A. and El-Shazely H.S. 2008. Water quality management scenarios in Rosetta River Nile branch, Egypt. 12 ${ }^{\text {th }}$ Int. water technology Conf., Alex., Egypt, pp. 901-912.

El-Gohary F.A. 1994. Industrial wastewater management in Egypt. Cairo: Italian-Egyptian Study Days on the Environment.

El-Sayed, S. 2011. Physicochemical studies on the impact of pollution up on the River Nile branches, Egypt. M.Sc., Fac. of Sci., Benha Univ., Egypt.

Encyclopedia Britannica, 2017. Blue Nile River, Africa. Archived from the original on $1^{\text {st }}$ August 2017.

Ezzat, S.M. 2008. Role of certain botanical extracts against bacteria isolated from Nile River and drainage water. Ph.D., Fac. of Sci., Ain Shams Univ., Cairo, Egypt.

Ezzat, S.M.; Abo-Astate, M.A.; Mahdy, H.M.; Abd El Shakour, E.H. and El-Bahnasawy, M.A. 2014. The effect of ionizing radiation on multidrug resistant $P$. aeruginosa isolated from aquatic environments in Egypt. Brit. Micro. Res. J., 4:856868.

Ezzat, S.M.; Mahdy, H.M.; Abo-Astate, M.A.; Abd El Shakour, E.H. and El-Bahnasawy, M.A. 2012. Water quality assessment of River Nile at Rosetta branch: Impact of drains discharge. Middle-East J. Sci. Res., 12:413- 423.

Food and Agriculture Organization "FAO" (1997): Management of Agriculture Water Quality. Water reports, PP. 8, ISSN, 1020-1203, Rome

Garg, R.K.; Rao, R.J.; Uchchariya, D.; Shukla, G. and Saksena, D.N. 2010. Seasonal variations in water quality and major threats to Ramsagar reservoir. India. Afr. J. Environ. Sci. Technol., 4:61-76.

George, I.; Anzil, A. and Servais, P.2004. Quantification of fecal coliform inputs to aquatic systems through soil leaching. Water Res., 38:611618.

Giannoulis, N.; Maipa, V.; Konstantinou, I.; Albanis, T. and Dimoliatis, I. 2005. Microbiological risk assessment of Agios Georgios source supplies in north western Greece based on faecal coliform determination and sanitary inspection survey. Chemosphere, 58:1269-1276.

Gloterman, H.L.; Clymo, R.S. and Ohnstad, M.A.M. 1978. Methods for Physical and Chemical Analysis of Fresh Water. The $2^{\text {nd }}$ ed., IBP Hand book No. 8. Blackwell Scientific Publications. Oxford. 
Gordon, D.M. and FitzGibbon, F. 1999. The Distribution of Enteric Bacteria from Australian Mammals: Host and Geographical Effects. Microbiology, 145:2663-2671.

Ibrahim, A. M.; Kamel, S. A.; OMAR, A. S. and Madkour, H. A. 2017 a. Assessment of Pollution Sources on Rosetta Branch, Egypt. Nature Sci., 15(6):126-144.

Ibrahim, A. M.; Kamel, S. A.; OMAR, A. S. and Madkour, H. A. 2017 b. Environmental Impacts of Metal Pollution Sources on Rosetta Branch Water Quality. Nature Sci., 15(7):117-123.

Moustafa, M.M.; Ali, M.H.; Abdel-Satar, A.M.; Mohamed, T.Y. and Madbouly, S.M. 2010. Water quality assessment of Rosetta and Damietta branch, River Nile, Egypt. African J. Biol. Sci., 6:127-142.

Pettibone, G.W. 1992. The use of lauryal treptose broth containing 4-methyl umbelliferyl-beta-Dglucuronide "MUG" to enumerate $E$. coli form fresh water sediment. Lett. Appl. Microbiol., 15(5):190-192.

Rabeh, S.A. 2009. Bacteria and Viruses in the Nile, in the Nile: Environments, limnology and human use, by H.J. Dumont(ed.), Springer Science+ Business Media B.V.

Rifaat, A.W. and I. B. Mohamed 2004. Water quality assessment of the river Nile system: an overview. Biomed. Environ. Sci. (BES), 17:87100.

Sabae, S.Z. and Rabeh, S.A. 2007. Evaluation of the microbial quality of the River Nile waters at Damietta branch, Egypt. Egypt. J. Aqua. Res., 33:301-311.

Sabea, S.Z.; Hazzaa, M.M.; Abdel-Halim, S.A.; Awni, N.M. and Dabbour, S.M. 2006. Studies on the bacterial indicators of water pollution and bioremediater isolates for $\mathrm{Cu}^{2+}, \mathrm{Fe}^{2+}$ and $\mathrm{Zn}^{2+}$ in Rosetta branch, river Nile, Egypt. Egypt J. Biotech., 22:77-103.

Salvini, R.; Carmignani, L.; Francionib, M. and Casazzaa, P. 2015. Elevation modelling and palaeo-environmental interpretation in the Siwa area (Egypt): Application of SAR interferometry and radargrammetry to COSMO-SkyMed imagery". Catena., 129:46-62.

Stirling, H.P. 1985. Chemical and biological methods of water analysis for aqua culturists. Institute of Aquaculture, University of Stirling, Scotland.

Tayel, S.I.; Yacoub, A.M. and Mahmoud, S.A. 2008. Histopathological and hematological responses to freshwater pollution in catfish Clarias gariepinus. J. Egypt. Acad. Soc. Environ. Develop., 9:43-60.$$
\text { التقييم الميكروييولوجي والقيزيوكيميائي لنهر النيل (فرع رشيد) }
$$$$
\text { أمينة إبراهيم سليمان '، راشد عبدالفتاح زغلول'، رشا محمد الميهى'، إحسان أحمد حنفى'، حاتم محمد على' }
$$$$
\text { ا بوحدة نوعية المياه، وزارة الري والموارد المائية، جمهورية مصر العربية. }
$$

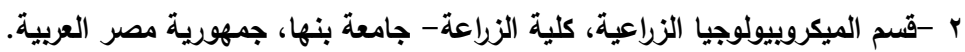

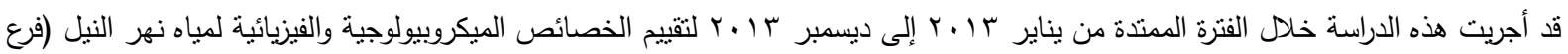

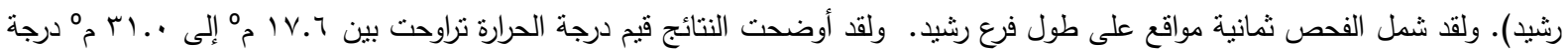

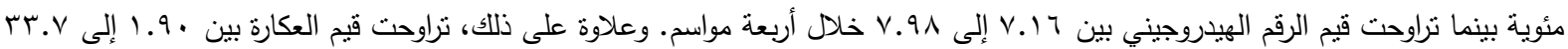
خلال جميع الفصول. أما فيما يتعلق بقيمة الأكسجين المذاب، فقد سجلت أدنى قيمة ( ا.ب ملليجرام / لتز ) وأعلى قيمة ( . . ملإيجرام / لتر )

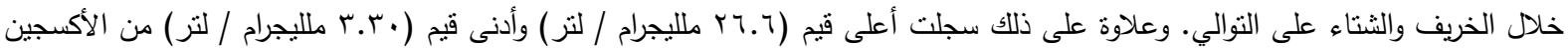

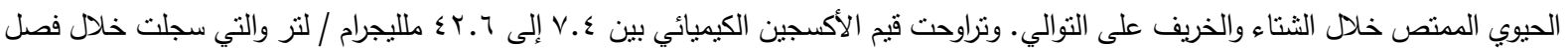

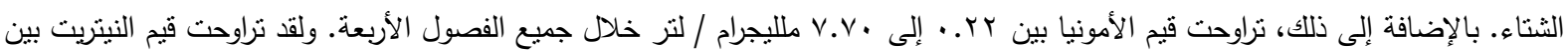

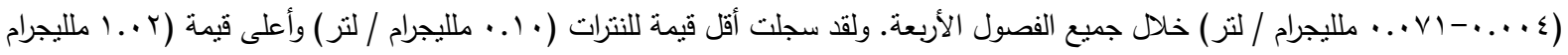

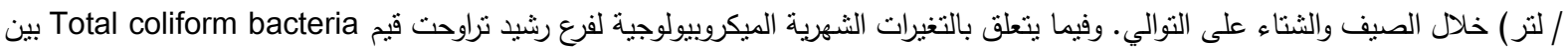

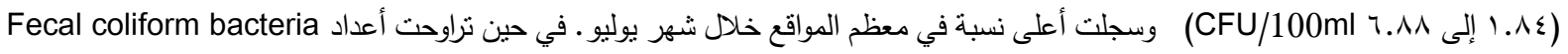

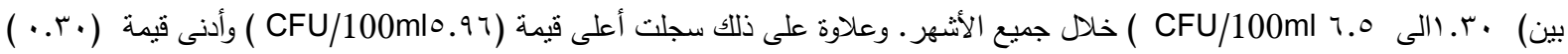

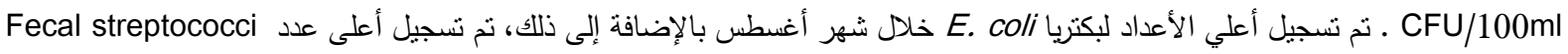

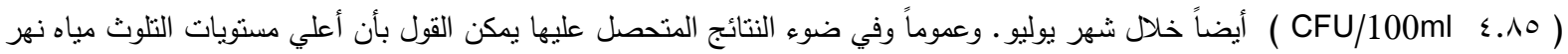

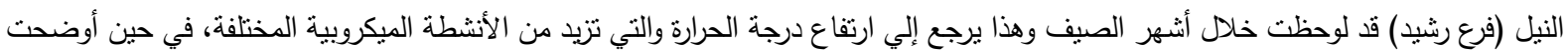

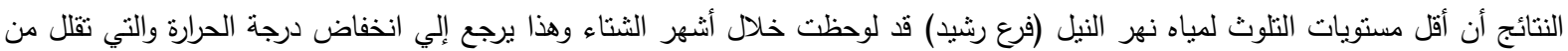

